\title{
The Relationship between Economic Growth, Energy Consumption and Carbon Dioxide Emissions: Evidence from Central Asia
}

\author{
Anh Tru NGUYEN*
}

Received: May 31, 2019. Revised: November 23, 2019. Accepted: November 26, 2019.

\begin{abstract}
This article aims to explore the relationship between economic growth, energy consumption and $\mathrm{CO}_{2}$ emissions of five Central Asian countries between 1998 and 2017. We found that per capita energy consumption has a positive relationship with per capita GDP, while per capita $\mathrm{CO}_{2}$ emissions negatively affect per capita GDP in Central Asia. Further, per capita GDP has a negative impact on per capita energy consumption in the region. Results reflect that the economic growth of Central Asian countries still heavily depends upon energy consumption. However, $\mathrm{CO}_{2}$ emissions in this region should be reduced because it has been defined as a determinant leading to a decrease in economic growth. In the short run, we also found that there is a directional relationship running from per capita GDP to per capita energy consumption and per capita $\mathrm{CO}_{2}$ emissions; and from per capita energy consumption to per capita GDP. Results show that there is a co-integration among variables in the long run. Finally, policies are recommended to enhance economic growth and achieve sustainable development in Central Asia.
\end{abstract}

Keywords: Economic growth, energy consumption, carbon dioxide emission, Central Asia

JEL Code Classification: 013, 047, Q43

UDC: 338.1

DOI: https://doi.org/10.17015/ejbe.2019.024.01

\footnotetext{
* PhD, Department of Marketing, Faculty of Accounting and Business Management, Viet Nam National University of Agriculture, Trau Quy, Gia Lam, Ha Noi, Viet Nam, E-mail: nguyenanhtru@vnua.edu.vn. 
The Relationship between Economic Growth, Energy Consumption and Carbon Dioxide...

\section{Introduction}

In the past 25 years, since achieving independence from the Soviet Union, Central Asia includes five culturally and ethnically diverse countries that have followed different paths to political and economic transformation. For example, while Kazakhstan and Kyrgyzstan have tremendous progress in market reforms, transitions to the market economy in Turkmenistan and Uzbekistan have not yet completed. Tajikistan is known as an intermediate case. After more than a decade of growth relied on hydrocarbon booms, Central Asian countries are facing obstacles related to decreasing commodity prices, declining trade and lower migrant remittances (Batsaikhan and Dabrowski, 2017). The economic growth of Central Asian countries is predicted to reach 3.1 percent in 2017 and accelerated to 4.1 percent in 2018, but each country grows at different rates. Most economies in the region have to face internal and external imbalances, that request responses from the governments through implementing fiscal, monetary and structural policies (Samruk-Kazyna, 2017). Central Asia's economy heavily depends upon international prices for energy and metals, which attracted foreign direct investment into oil and gas extraction industries and transport infrastructure (ADBI, 2014).

The geopolitical position of Central Asia is more important in recent years due to two reasons, consisting of the availability of rich energy resources and this region is a high interest of the US, the EU, Russian Federation, China, and other international actors to reveal their power in international relation (Rakhimov, 2010). However, the relationship between economic growth, energy consumption and carbon dioxide $\left(\mathrm{CO}_{2}\right)$ emissions in Central Asia is still an ambiguous theme. What is the relationship between economic growth, energy consumption and $\mathrm{CO}_{2}$ emissions in Central Asia? How do these variables correlate in the short run and long run? A major contribution of this study to the existing literature is to examine the causal relationship between economic growth, energy consumption, and $\mathrm{CO}_{2}$ emissions of five Central Asian countries in the period 1998-2017 using the vector autoregressive (VAR) model. More importantly, policies are recommended to the governments of Central Asian countries to achieve sustainable development in the region.

The remainder of this paper is structured as follows. Section 2 presents an empirical review. Research methods are discussed in section 3 . In section 4 , we present results and discussion. Finally, the conclusion and policy implications are summarized in section 5 .

\section{Empirical Review}

The relationship between economic growth, energy consumption and $\mathrm{CO}_{2}$ emissions is widely discussed by scholars in the world. Aye and Edoja (2017) estimated the impact of economic growth on $\mathrm{CO}_{2}$ emission in 31 developing countries. They found that economic growth has a negative effect on $\mathrm{CO}_{2}$ emission in the low growth regime, but it positively affects $\mathrm{CO}_{2}$ emission in the high growth regime. Likewise, 
Bakirtas and Akpolat (2018) investigated the relationship between energy consumption, urbanization and economic growth of six emerging countries between 1971 and 2014. Results showed that there is a Granger causality running from economic growth to energy consumption, and from urbanization to energy consumption and economic growth. A study by Al-mulali et al. (2013) examined the relationship between energy consumption, $\mathrm{CO}_{2}$ emission and economic growth in Latin America and the Caribbean from 1980 to 2008. Results indicated that there is a long-run relationship between these variables in 60 percent of countries, and the rest (40 percent) presents a mixed result.

Further, Wang et al. (2018) investigated the relationship between urbanization, economic growth, energy consumption, and $\mathrm{CO}_{2}$ emissions of 170 countries between 1980 and 2011. Results demonstrated that a co-integration relationship existed between variables in all the countries studied, and there is a statistically significant positive relationship existed between variables in the long run. Besides, they found that evidence of varied Granger causality relationships between the variables across the income-based subpanels. Similarly, Zhang and Cheng (2009) examined the relationship between economic growth, energy consumption and $\mathrm{CO}_{2}$ emissions in China from 1960 to 2007. Results showed that neither carbon emissions and energy consumption contributes to economic growth. A study by Destek (2016) investigated the relationship between military spending and economic growth in newly industrialized countries between 1988 and 2013. He found that the growth hypothesis is supported for India, Malaysia, Mexico, and South Africa, while the neutrality hypothesis has been found in China, Indonesia, the Philippines, Thailand, and Turkey, and the growth detriment hypothesis has been diagnosed for Brazil. Aziz and Dahalan (2015) assessed impacts of oil price shocks on real economic activities in ASEAN-5 for the period 1991-2014. Results indicated that positive oil price shock measures negatively influence output growth both in the short term and long term. In terms of oil price decrease specifications, they found that real output is negative in the short term before recovering to its pre-shock level in the long term.

Asumadu-Sarkodie and Owusu (2017) investigated the relationship between $\mathrm{CO}_{2}$ emissions, gross domestic product (GDP) per capita, industrialization, and population in Rwanda over the period 1965-2011. They found that a 1 percent increase in GDP per capita leads to a decrease of $\mathrm{CO}_{2}$ emissions by 1.45 percent, but a 1 percent increase in industrialization will increase $\mathrm{CO}_{2}$ emissions by 1.64 percent in the long-run. Likewise, Hundie (2018) assessed the relationship between energy consumption, $\mathrm{CO}_{2}$ emissions and economic growth in Ethiopia between 1970 and 2014. Results showed that energy consumption, population, trade openness and economic growth have a positive effect on $\mathrm{CO}_{2}$ in the long-run, while economic growth squared has a negative relationship with $\mathrm{CO}_{2}$ emissions. Lastly, Danish et al. (2018) examined the relationship between energy production, economic growth and $\mathrm{CO}_{2}$ emission in Pakistan for the period 1970-2011. They found that there is an existence of an environmental Kuznets curve hypothesis in the significance of energy 
The Relationship between Economic Growth, Energy Consumption and Carbon Dioxide...

production in Pakistan. In addition, bidirectional causality is distinguished between energy production and $\mathrm{CO}_{2}$ emission in the long-run.

\section{Methodology}

\subsection{Data and Sources}

A panel dataset for the relationship between economic growth, energy consumption, and $\mathrm{CO}_{2}$ emissions in Central Asia is gathered from the World Development Indicators released by the World Bank. Specifically, a panel dataset is collected in five Central Asian countries, including Kazakhstan, Kyrgyzstan, Tajikistan, Turkmenistan, and Uzbekistan, for the last two decades (1998-2017). Thus, a total of 100 observations is entered for data analysis. The panel data is used for this research because of the following advantages: (1) it benefits in terms of obtaining a large sample, giving more degree of freedom, more information, and less multicollinearity among variables; and (2) it may overcome constraints related to control individual or time heterogeneity faced by the cross-sectional data (Hsiao, 2014).

\subsection{The Vector Autoregressive (VAR) Model}

The VAR model is used to examine the causality between economic growth, energy consumption, and $\mathrm{CO}_{2}$ emissions in Central Asian countries for the period 19982017. The VAR model is chosen for this study because it interprets the endogenous variables solely by their history, apart from deterministic regressors and therefore, this method incorporates non-statistical a priori information (Pfaff, 2008). In addition, the VAR model is a popular method in economics and other sciences since it is a simple and flexible model for multivariate time series data (Suharsono et al., 2017).

The specification of a VAR model can be defined as follows (Pfaff, 2008):

$Y_{t}=A_{1} Y_{t-1}+\cdots+A_{p} Y_{t-p}+\varepsilon_{t}$

Where: $Y_{t}$ denotes a set of $K$ endogenous variables such as per capita GDP, per capita energy consumption and per capita $\mathrm{CO}_{2}$ emissions; $A_{i}$ represents $(K \times K)$ coefficient matrices for $i=1, \ldots, p$; and $\varepsilon_{t}$ is a K-dimensional process with $E\left(\varepsilon_{t}\right)=0$.

An important characteristic of the VAR model is stability, and therefore it generates a stationary time series with time-invariant means, variances, and covariance structure, given sufficient starting values. This characteristic can be checked by evaluating the equation as follows:

$\operatorname{det}\left(I_{k}-A_{1} z-\cdots-A_{p} z^{p}\right) \neq 0$ for $[z]=1$

Where: $I_{k}$ denotes the number of orders; $A_{i}$ represents $(K \times K)$ coefficient matrices for $i=1, \ldots, p$; and $z$ represents the number of roots. 
If the solution of the above equation has a root for $z=1$, then either some or all variables in the $\operatorname{VAR}(p)$-process are integrated of order one, i.e., I(1).

The stability of an empirical VAR model can be analyzed by considering the companion form and computing the eigenvalues of the coefficient matrix. A VAR model may be specified as follows (Pfaff, 2008):

$\varepsilon_{t}=A \varepsilon_{t-1}+V_{t}$

Where: $\varepsilon_{t}$ denotes the dimension of the stacked vector; $A$ is the dimension of the matrix $\left(K_{p} \times K_{p}\right)$, and $V_{t}$ represents $(K P \times 1)$.

Indicators of the equation (3) can be calculated as follows:

$$
\varepsilon_{t}=\left[\begin{array}{c}
Y_{t} \\
\vdots \\
Y_{t-p+1}
\end{array}\right] ; A=\left[\begin{array}{ccccc}
A_{1} & A_{2} & \ldots & A_{p-1} & A_{p} \\
I & 0 & \ldots & 0 & 0 \\
0 & I & \ldots & 0 & 0 \\
\vdots & \vdots & \ddots & \vdots & \vdots \\
0 & 0 & \ldots & I & 0
\end{array}\right] ; V_{t}=\left[\begin{array}{c}
U_{t} \\
0 \\
\vdots \\
0
\end{array}\right]
$$

Table 1. Description of Covariates in the VAR Model

\begin{tabular}{ll}
\hline Variable definitions & Unit \\
\hline Per capita GDP & USD \\
Per capita energy consumption & kg of oil \\
Per capita $\mathrm{CO}_{2}$ emissions & metric ton \\
\hline Note: USD means United States Dollar &
\end{tabular}

In this research, the procedure of a VAR model includes six steps, consisting of (1) performing the unit root test; (2) determining lag length; (3) estimating the VAR model; (4) testing the Granger causality; (5) checking the stability of eigenvalues; and (6) implementing the Johansen test for co-integration. The VAR model is estimated by the Stata MP 14.2 software.

\section{Results and Discussion}

\subsection{Economic Growth, Energy Consumption and $\mathrm{CO}_{2}$ Emissions in Central Asia: An Overview}

The average per capita GDP, energy consumption, and CO2 emissions of Central Asian countries account for USD2,512, 1,746 kg of oil, and 4.8 metric tonnes, respectively (Table 2 ).

Table 2. Characteristics of Economic Growth, Energy Consumption and $\mathrm{CO}_{2}$ Emissions in Central Asia

\begin{tabular}{lcccc}
\hline Variable & Mean & SD & Min & Max \\
\hline Per capita GDP & 2512.79 & 3223.02 & 138.4 & 13890.6 \\
Per capita energy consumption & 1746.05 & 1674.43 & 0 & 4893.5
\end{tabular}


The Relationship between Economic Growth, Energy Consumption and Carbon Dioxide...

Per capita $\mathrm{CO}_{2}$ emissions

4.82

5.01

0

15.6

Source: Author's calculation, 2019, Note: SD denotes standard deviation

For the last two decades (1998-2017), the per capita GDP of five countries increased, especially in Kazakhstan and Turkmenistan. For instance, by 2017, the per capita GDP of Kazakhstan reached more than USD9,000 which was higher than that in 1998 by more than six times. In the same period, the per capita GDP of Turkmenistan accounted for more than USD6,500, which was higher than that in 1998 by more than 11 times. Tajikistan had the lowest per capita GDP in the region, with about USD800 in 2017 (Figure 1).

16,000

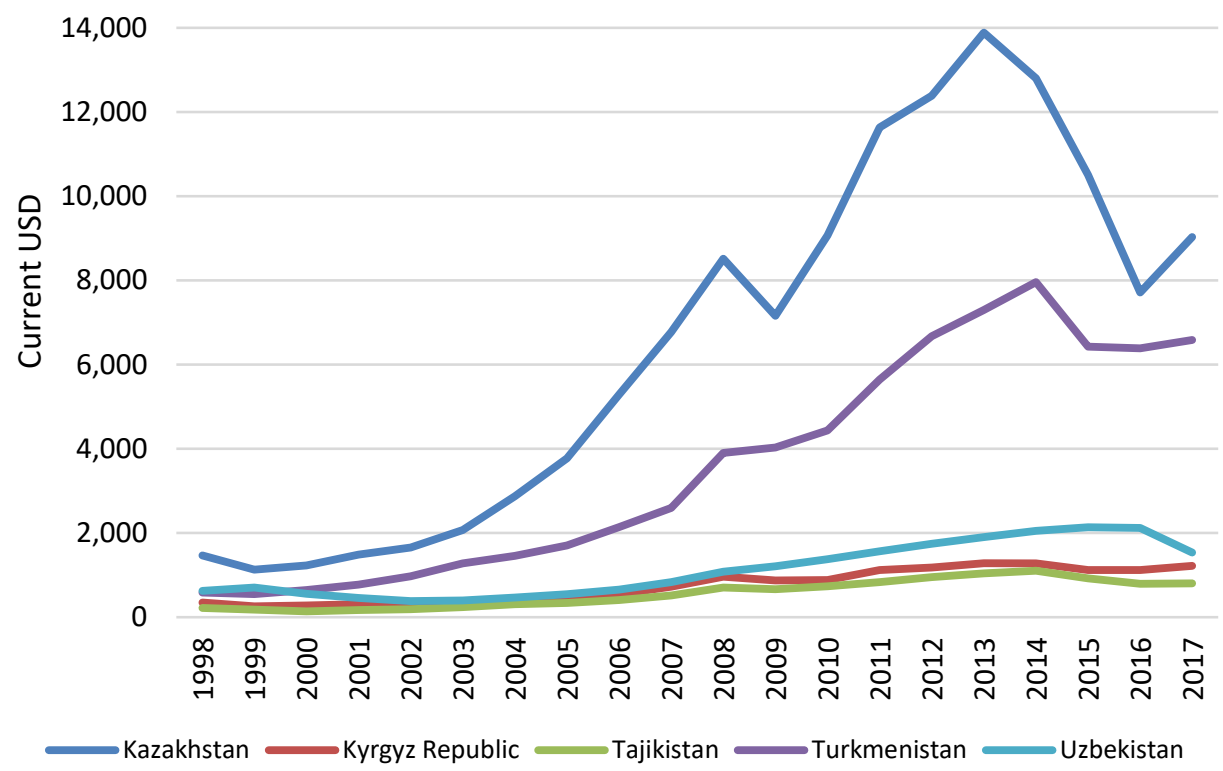

Figure 1. Per Capita GDP of Selected Countries in Central Asia

Source: World Bank, 2019

From 1998 to 2014, per capita, the energy consumption of Turkmenistan and Kazakhstan significantly increased, while per capita energy consumption of the Kyrgyz Republic had a slight increase. By contrast, per capita, the energy consumption of Uzbekistan and Tajikistan declined in the same period. By 2014, per capita, the energy consumption of Turkmenistan reached more than $4,800 \mathrm{~kg}$ of oil, which was higher than that in 1998 by more than 1.7 times. In the same period, per capita, the energy consumption of Kazakhstan accounted for more than $4,400 \mathrm{~kg}$ of oil, which was higher than that in 1998 by more than 1.6 times (Figure 2). 
Anh Tru Nguyen

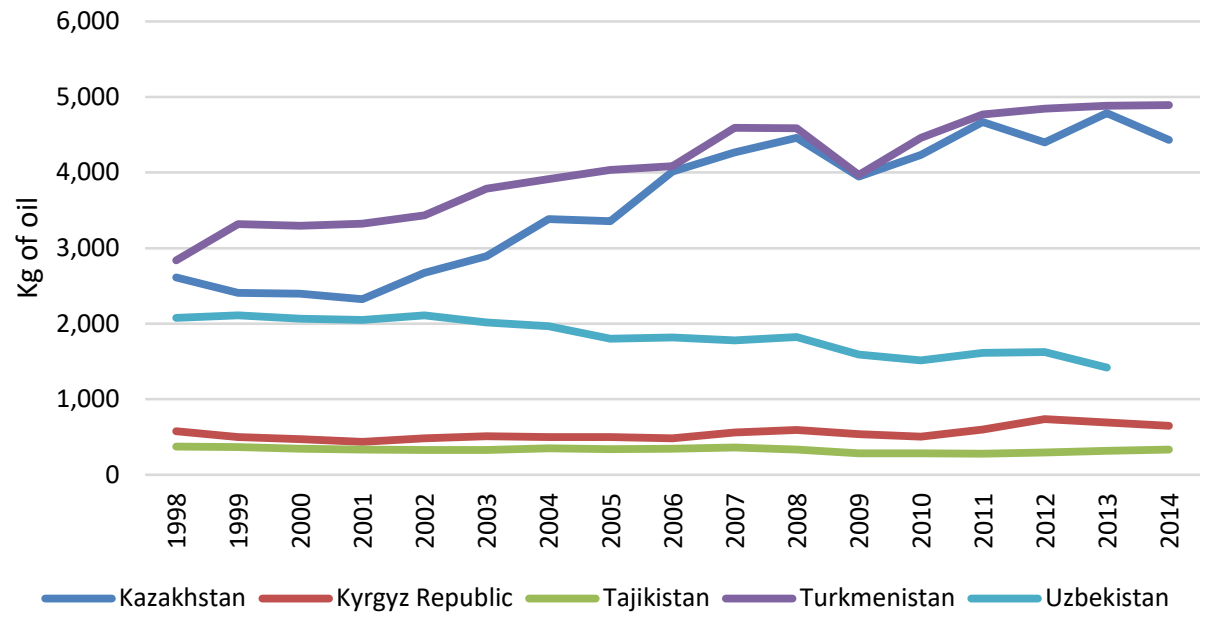

Figure 2. Per Capita Energy Consumption of Selected Countries in Central Asia Source: World Bank, 2019

For the period 1998-2014, Kazakhstan had the highest per capita $\mathrm{CO}_{2}$ emissions, followed by Turkmenistan, Uzbekistan, the Kyrgyz Republic, and Tajikistan. Per capita, $\mathrm{CO}_{2}$ emissions of Kazakhstan rapidly increased by 6 metric tonnes from 8.4 metric tonnes in 1998 to 14.4 metric tonnes in 2014. In the same period, per capita $\mathrm{CO}_{2}$ emissions of Turkmenistan increased by 5.2 metric tonnes, while per capita $\mathrm{CO}_{2}$ emissions in Uzbekistan decreased by 1.6 metric tonnes. Results suggest that countries, which have higher economic growth and energy consumption, have a higher level of $\mathrm{CO}_{2}$ emissions (Figure 3).

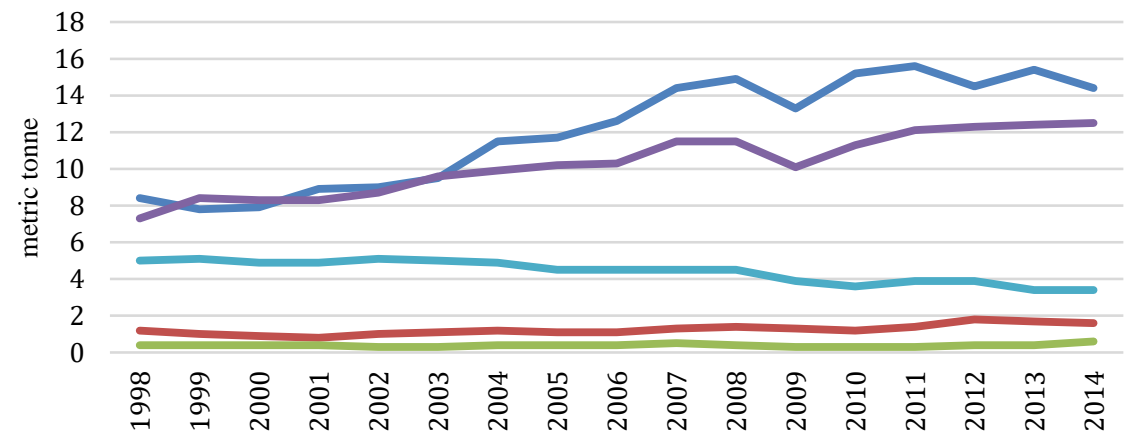

$\longrightarrow$ Kazakhstan $\longrightarrow$ Kyrgyz Republic $\longrightarrow$ Tajikistan $\longrightarrow$ Turkmenistan $\longrightarrow$ Uzbekistan

Figure 3. Per Capita $\mathrm{CO}_{2}$ Emissions of Selected Countries in Central Asia Source: World Bank, 2019 
The Relationship between Economic Growth, Energy Consumption and Carbon Dioxide...

\subsection{The Relationship between Economic Growth, Energy Consumption and $\mathrm{CO}_{2}$ Emissions in Central Asia}

\subsubsection{Implementation of the Unit Root Test}

The unit root test is carried out to check the stationarity of the time series variables (Adeola and Ikpesu, 2016). In this study, the Augmented Dickey-Fuller (ADF) test is used to examine the stationarity of economic growth, energy consumption, and $\mathrm{CO}_{2}$ emissions with the hypothesis as follows:

Null hypothesis $\left(\mathrm{H}_{0}\right)$ : The variables contain a unit root

The alternative hypothesis $\left(\mathrm{H}_{\mathrm{a}}\right)$ : The variables do not contain a unit root

Results show that we cannot reject the null hypothesis because the P-values of all variables is greater than critical values at $1 \%, 5 \%$, and $10 \%$, respectively, and these imply that variables exhibit a unit root (Table 3 ).

\section{Table 3. The ADF Test for the Unit Root}

\begin{tabular}{|c|c|c|c|}
\hline Variables & Level & $1^{\text {st }}$ difference & $2^{\text {nd }}$ difference \\
\hline LnPer capita & T-statistic: -2.08 & T-statistic: -2.30 & T-statistic: -2.67 \\
\hline \multirow[t]{5}{*}{ GDP } & P-value: 0.25 & P-value: 0.17 & P-value: 0.07 \\
\hline & Critical values: & Critical values: & Critical values: \\
\hline & 1\% level: -3.51 & 1\% level: -3.51 & 1\% level: -3.51 \\
\hline & 5\% level: -2.89 & 5\% level: -2.89 & 5\% level: -2.89 \\
\hline & 10\% level: - -2.58 & 10\% level: -2.58 & 10\% level: -2.58 \\
\hline \multirow{6}{*}{$\begin{array}{l}\text { LnPer capita } \\
\text { energy } \\
\text { consumption }\end{array}$} & T-statistic: -3.88 & T-statistic: -4.35 & T-statistic: -5.01 \\
\hline & P-value: 0.00 & P-value: 0.00 & P-value: 0.00 \\
\hline & Critical values: & Critical values: & Critical values: \\
\hline & 1\% level: -3.51 & 1\% level: -3.51 & 1\% level: -3.51 \\
\hline & 5\% level: -2.89 & 5\% level: -2.89 & 5\% level: -2.89 \\
\hline & $10 \%$ level: -2.58 & 10\% level: -2.58 & $10 \%$ level: -2.58 \\
\hline \multirow{6}{*}{$\begin{array}{l}\text { LnPer capita } \\
\mathrm{CO}_{2} \\
\text { emissions }\end{array}$} & T-statistic: -1.97 & T-statistic: -2.04 & T-statistic: -2.05 \\
\hline & P-value: 0.29 & P-value: 0.26 & P-value: 0.26 \\
\hline & Critical values: & Critical values: & Critical values: \\
\hline & 1\% level: -3.51 & 1\% level: -3.51 & 1\% level: -3.51 \\
\hline & 5\% level: -2.89 & 5\% level: -2.89 & 5\% level: -2.89 \\
\hline & 10\% level: - -2.58 & 10\% level: -2.58 & 10\% level: -2.58 \\
\hline
\end{tabular}

Source: Author's calculation, 2019

\subsubsection{Determination of the Lag Length}

The purpose of this step is to specify the optimal lag for the VAR model. If the lag is used too little, then the residual of the regression will not show the white noise process, and as a result, the actual error could not be accurately estimated by the model (Suharsono et al., 2017). 
Anh Tru Nguyen

As seen in Table 4, results suggest that the optimal lag length, in this case, is four lags because this value is recommended by FPE, AIC, and HQIC indicators, while SBIC only recommends one lag. Therefore, four lags (the number of lag is equal to 4 ) is chosen to run the VAR model in the next step.

Table 4. Selection of the Lag Length

\begin{tabular}{ccccccccc}
\hline Lag & LL & LR & df & P & FPE & AIC & HQIC & SBIC \\
\hline 0 & -492.63 & & & & 6.122 & 10.325 & 10.358 & 10.405 \\
1 & -284.29 & 416.67 & 9 & 0.00 & 0.096 & 6.172 & 6.302 & $6.493^{*}$ \\
2 & -275.55 & 17.47 & 9 & 0.04 & 0.096 & 6.178 & 6.405 & 6.739 \\
3 & -252.94 & 45.22 & 9 & 0.00 & 0.073 & 5.894 & 6.218 & 6.696 \\
4 & -228.20 & $49.49^{*}$ & 9 & 0.00 & $0.052^{*}$ & $5.566^{*}$ & $5.987^{*}$ & 6.608 \\
\hline
\end{tabular}

Endogenous: LnGDP LnEnergy consumption $\mathrm{LnCO}_{2}$ emissions, Exogenous: Constant

Number of bservations $=96$

Source: Author's calculation, 2019

Notes: *denotes lag order selected by the criterion; LL means log likelihood values; LR represents sequential modified LR test statistics; FPE denotes final prediction error; AIC means Akaike information criterion; HQIC represents Hannan-Quinn information criterion, and SBIC means Schwarz's Bayesian information criterion.

\subsubsection{Estimation of the VAR Model}

We found that per capita energy consumption has a positive relationship with per capita GDP, while per capita $\mathrm{CO}_{2}$ emissions negatively affect per capita GDP in Central Asia. Moreover, per capita GDP has a negative effect on per capita energy consumption (see details in Table A1 of the appendices).

\subsubsection{Testing the Granger Causality}

The objective of this step is to assess the predictive capacity of a single variable on other variables (Musunuru, 2017). In this research, hypotheses need to be tested as follows:

- Testing the relationship between per capita GDP and other variables:

Null hypothesis $\left(\mathrm{H}_{0}\right)$ : Per capita GDP does not cause per capita energy consumption and per capita $\mathrm{CO}_{2}$ emissions

The alternative hypothesis $\left(\mathrm{H}_{\mathrm{a}}\right)$ : Per capita GDP causes per capita energy consumption and per capita $\mathrm{CO}_{2}$ emissions

- Testing the relationship between per capita energy consumption and other variables:

Null hypothesis $\left(\mathrm{H}_{0}\right)$ : Per capita energy consumption does not cause per capita GDP and per capita $\mathrm{CO}_{2}$ emissions

The alternative hypothesis $\left(\mathrm{H}_{\mathrm{a}}\right)$ : Per capita energy consumption causes per capita GDP and per capita $\mathrm{CO}_{2}$ emissions

- Testing the relationship between per capita $\mathrm{CO}_{2}$ emissions and other variables: 
The Relationship between Economic Growth, Energy Consumption and Carbon Dioxide...

Null hypothesis $\left(\mathrm{H}_{0}\right)$ : Per capita $\mathrm{CO}_{2}$ emissions do not cause per capita GDP and per capita energy consumption

The alternative hypothesis $\left(\mathrm{H}_{\mathrm{a}}\right)$ : Per capita $\mathrm{CO}_{2}$ emissions cause per capita GDP and per capita energy consumption

We found that there is a directional relationship running from per capita GDP to per capita energy consumption and per capita $\mathrm{CO}_{2}$ emissions, and from per capita energy consumption to per capita GDP (Table 5).

\section{Table 5. Results of the Granger Causality Wald Test}

\begin{tabular}{lll}
\hline Directional relationship & Probability & Conclusion \\
\hline Per capita GDP $\longrightarrow$ Per capita energy consumption & $0.00<0.05$ & Reject $\mathrm{H}_{0}$ \\
Per capita GDP $\longrightarrow$ Per capita $\mathrm{CO}_{2}$ emissions & $0.00<0.05$ & Reject $\mathrm{H}_{0}$ \\
Per capita energy consumption $\longrightarrow$ Per capita GDP & $0.00<0.05$ & Reject $\mathrm{H}_{0}$ \\
Per capita energy consumption $\longrightarrow$ Per capita CO $\mathrm{CO}_{2}$ emissions & $0.07>0.05$ & Accept $\mathrm{H}_{0}$ \\
Per capita $\mathrm{CO}_{2}$ emissions $\longrightarrow$ Per capita GDP & $0.31>0.05$ & Accept $\mathrm{H}_{0}$ \\
Per capita $\mathrm{CO}_{2}$ emissions $\longrightarrow$ Per capita energy consumption & $0.10>0.05$ & Accept $\mathrm{H}_{0}$ \\
\hline
\end{tabular}

Source: Author's calculation, 2019

\subsubsection{Examination of Eigenvalue Stability}

The goal of this step is to examine the stability of the eigenvalues in the VAR model. All the eigenvalues lie inside the unit circle, and we can conclude that the VAR model satisfies stability condition (Figure 4).

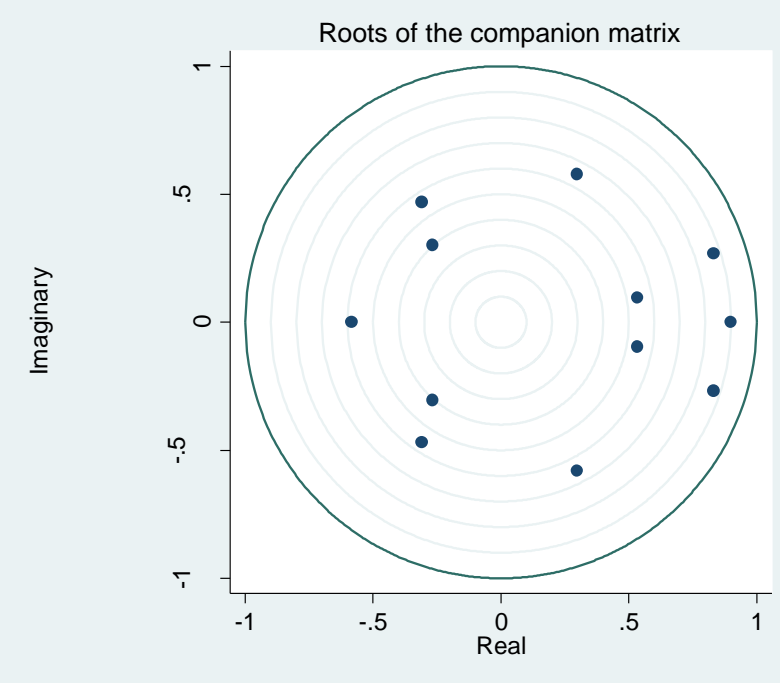

Figure 4. Checking the Eigenvalue Stability

Source: Author's calculation, 2019 


\subsubsection{Performance of the Johansen Co-integration Test}

The Johansen co-integration test is performed to examine the long-run relationship among variables. If variables are co-integrated, it suggests that there is a long term relationship among variables (Musunuru, 2017).

The hypothesis to be tested can be identified as follows:

Null hypothesis $\left(\mathrm{H}_{0}\right)$ : There is no co-integration among variables

The alternative hypothesis $\left(\mathrm{H}_{\mathrm{a}}\right)$ : There is co-integration among variables

In this research, the Johansen co-integration test is carried out by the trace statistic test. Trace test is a likelihood-ratio-type test, which operates under different assumptions in the deterministic part of the data generation process (Lutkepohl et al., 2001).

As seen in Table 6, we cannot reject the null hypothesis in the rank one (one cointegration) because trace statistic is less than the $1 \%$ critical value $(17.09<20.04)$ and this implies that there is a co-integration among variables.

Table 6. Results of Trace Statistic in the Johansen Co-integration Test

\begin{tabular}{cccccc}
\hline $\begin{array}{c}\text { Maximum } \\
\text { rank }\end{array}$ & LL & Eigenvalue & $\begin{array}{c}\text { Trace } \\
\text { statistic }\end{array}$ & $\begin{array}{c}\mathbf{5 \%} \text { critical } \\
\text { value }\end{array}$ & $\begin{array}{c}\mathbf{1 \%} \text { critical } \\
\text { value }\end{array}$ \\
\hline 0 & -247.49 & & 38.58 & 29.68 & 35.65 \\
1 & -236.75 & 0.200 & $17.09^{* 1}$ & 15.41 & 20.04 \\
2 & -230.31 & 0.125 & 4.23 & 3.76 & 6.65 \\
3 & -228.20 & 0.043 & & & \\
\hline
\end{tabular}

Source: Author's calculation, 2019 , Notes: ${ }^{* 1}$ denotes the number of co-integration (ranks) chosen to accept the null hypothesis at $1 \%$ critical value

\subsection{Discussion}

We found that per capita energy consumption has a positive relationship with per capita GDP, while per capita $\mathrm{CO}_{2}$ emissions negatively affect per capita GDP in Central Asia. Further, per capita GDP has a negative impact on per capita energy consumption in the region. Results reflect that the economic growth of Central Asian countries still heavily depends upon energy consumption. However, $\mathrm{CO}_{2}$ emissions in this region should be reduced because it has been defined as a determinant leading to a decrease in economic growth.

In the short run, we found that there is a directional relationship running from per capita GDP to per capita energy consumption and per capita $\mathrm{CO}_{2}$ emissions; and from per capita energy consumption to per capita GDP. Results show that there is a cointegration among variables in the long run. Central Asia is a mix region, which includes upper, middle, and low-income economies, with heavy dependence on the extraction and export of energy products. Coal and oil production is dominated by 
The Relationship between Economic Growth, Energy Consumption and Carbon Dioxide...

Kazakhstan, while Turkmenistan is known as the region's largest producer of natural gas. In this region, the primary energy supply is dominated by fossil fuels (UN, 2019).

Central Asian countries need to consume more energy to foster economic growth. However, renewable energy sources such as solar, wind, and hydropower should be facilitated to exploit by countries in the region to reduce the dependence of these countries on fossil fuel energy. For instance, hydropower plays an important role in Tajikistan and Kyrgyzstan. Although the regional economic growth trend has been determined by rising gas and oil exports in Kazakhstan and Turkmenistan, this generates a lower regional energy intensity measured by the energy consumed per dollar of GDP produced. In Central Asia, countries benefit from high solar and wind potential in many areas, but these potentials have just begun to be exploited by some countries. Renewable energy is primarily consumed in the form of electricity in residential and industrial sectors (UN, 2019). Finally, $\mathrm{CO}_{2}$ emissions in the region should be managed to achieve sustainable development.

\section{Conclusion and Policy Implications}

This article explores the relationship between economic growth, energy consumption, and $\mathrm{CO}_{2}$ emissions of five Central Asian countries between 1998 and 2017. We found that per capita energy consumption has a positive relationship with per capita GDP, while per capita $\mathrm{CO}_{2}$ emissions negatively affect per capita GDP in Central Asia. Further, per capita GDP has a negative impact on per capita energy consumption in the region. Results reflect that the economic growth of Central Asian countries still heavily depends upon energy consumption. However, $\mathrm{CO}_{2}$ emissions in this region should be reduced because it has been defined as a determinant leading to a decrease in economic growth. In the short run, we also found that there is a directional relationship running from per capita GDP to per capita energy consumption and per capita $\mathrm{CO}_{2}$ emissions; and from per capita energy consumption to per capita GDP. Results show that there is a co-integration among variables in the long run.

Policies are recommended to enhance economic growth and achieve sustainable development in Central Asia. First, reduction of the dependence on fossil fuel energy by exploiting renewable energy sources such as solar, wind, and hydropower. In fact, obstacles occur in the region due to the presence of large natural resource rents (via the real appreciation of the exchange rate) to the development of internationally competitive manufacturing and service sectors. As a consequence, it leads to corruption and helps to consolidate authoritarian regimes (Batsaikhan \& Dabrowski, 2017). Although the increase of per capita energy consumption fosters economic growth of countries in the region, Central Asian countries should reduce exploitation of fossil fuel energy in order to ensure sustainable development. Second, $\mathrm{CO}_{2}$ emissions need to be controlled because it reduces economic growth in the region. For instance, poor air quality is found as a major reason of the vast majority of the population exposed to pollutant levels well above the WHO guideline (UN, 2019). 
Anh Tru Nguyen

Third, energy system in the region should be reformed to reduce government spending and improve the efficiency of the energy system. For example, in Central Asia, energy subsidies may facilitate wasteful consumption because it increases government spending and pushes prices below true costs. In addition, retail electricity prices are lower than the global average (UN, 2019). Lastly, regional cooperation and integration should be encouraged to ensure energy security and economic development (Rakhimov, 2010).

\section{References}

ADBI (2014). Connecting Central Asia with Economic Centers. A Study of the Asian Development Bank Institute, 2014.

Adeola, O., \& Ikpesu, F. (2016). An Empirical Investigation of the Impact of Bank Lending on Agricultural Output in Nigeria: A Vector Autoregressive (VAR) Approach. The Journal of Developing Areas, 50(6), 89-103. https://doi.org/10.1353/jda.2016.0140

Al-Mulali, U., Lee, J. Y., Mohammed, A. H., \& Sheau-Ting, L. (2013). Examining the Link between Energy Consumption, Carbon Dioxide Emission, and Economic Growth in Latin America and the Caribbean. Renewable and Sustainable Energy Reviews, 26, 42-48. https://doi.org/10.1016/j.rser.2013.05.041

Asumadu-Sarkodie, S., \& Owusu, P. A. (2016). Carbon Dioxide Emissions, GDP Per Capita, Industrialization and Population: An Evidence from Rwanda. Environmental Engineering Research, 22(1), 116-124. https://doi.org/10.4491/eer.2016.097

Aye, G. C., \& Edoja, P. E. (2017). Effect of Economic Growth on CO2 Emission in Developing Countries: Evidence from a Dynamic Panel Threshold Model. Cogent Economics \& Finance, 5(1), 1-22. https://doi.org/10.1080/23322039.2017.1379239

Aziz, M. I. A., \& Dahalan, J. (2015). Oil Price Shocks and Macroeconomic Activities in Asean-5 Countries: A Panel VAR Approach. Eurasian Journal of Business and Economics, 8(16), 101-120. DOI: 10.17015/ejbe.2015.016.06

Bakirtas, T., \& Akpolat, A. G. (2018). The Relationship between Energy Consumption, Urbanization, and Economic Growth in New Emerging-market Countries. Energy 147, 110-121. https://doi.org/10.1016/j.energy.2018.01.011

Batsaikhan, U., \& Dabrowski, M. (2017). Central Asia-Twenty-five Years after the Breakup of the USSR. Russian Journal of Economics 3(3), 296-320. https://doi.org/10.1016/j.ruje.2017.09.005

Danish, Zhang, B., Wang, Z., \& Wang, B. (2018). Energy Production, Economic Growth and CO2 Emission: Evidence from Pakistan. Natural Hazards, 90(1), 27-50. https://doi.org/10.1007/s11069-017-3031-z

Destek, M. A. (2016). The Nexus between Military Spending and Economic Growth in Newly Industrialized Countries: Panel Evidence from Cross-Sectional Dependency. Eurasian Journal of Business and Economics, 9(17), 37-50. https://doi.org/10.17015/ejbe.2016.017.03

Hsiao, C. (2014). Analysis of Panel Data. Third Edition, Cambridge University Press, New York. https://doi.org/10.1017/CBO9781139839327

Hundie, S. K. (2018). Modelling Energy Consumption, Carbon Dioxide Emissions and Economic Growth Nexus in Ethiopia: Evidence from Cointegration and Causality Analysis. Turkish Journal of Agriculture - Food Science and Technology, 6(6), 699-709. https://doi.org/10.24925/turjaf.v6i6.699-709.1720 
The Relationship between Economic Growth, Energy Consumption and Carbon Dioxide...

Lütkepohl, H., Saikkonen, P., \& Trenkler, C. (2001). Maximum Eigenvalue versus Trace Tests for the Cointegrating Rank of a VAR Process. The Econometrics Journal, 4(2), 287-310. https://doi.org/10.1111/1368-423X.00068

Musunuru, N. (2017). Causal Relationships between Grain, Meat Prices and Exchange Rates. International Journal of Food and Agricultural Economics, 5(4), 1-10.

Pfaff, B. (2008). VAR, SVAR and SVEC Models: Implementation within R Package Vars. Journal of Statistical Software, 27(4), 1-32. https://doi.org/10.18637/jss.v027.i04

Rakhimov, M. (2010). Internal and External Dynamics of Regional Cooperation in Central Asia. Journal of Eurasian Studies, 1(2), 95-101. https://doi.org/10.1016/j.euras.2010.04.002

Samruk-Kazyna (2017). Russia and Central Asia Macroeconomic Outlook 2017. Research \& Knowledge Management. Samruk-Kazyna, July 2017.

Suharsono, A., Aziza, A., \& Pramesti, W. (2017). Comparison of Vector Autoregressive (VAR) and Vector Error Correction Models (VECM) for Index of ASEAN Stock Price, in AIP Conference Proceedings 1913, 1, pp. 020032-1-020032-9. AIP Publishing. International Conference and Workshop on Mathematical Analysis and its Applications. https://doi.org/10.1063/1.5016666 UN (2019). Energy and Development in Central Asia: A Statistical Overview of Energy Sectors in Kazakhstan, Kyrgyzstan, Tajikistan, Turkmenistan, and Uzbekistan. The UN Special Programme for the Economies of Central Asia. The Economic and Social Commission for Asia and the Pacific, The United Nations 2019.

Wang, S., Li, G., \& Fang, C. (2018). Urbanization, Economic Growth, Energy Consumption, and CO2 Emissions: Empirical Evidence from Countries with Different Income Levels. Renewable and Sustainable Energy Reviews, 81, 2144-2159. https://doi.org/10.1016/j.rser.2017.06.025

World Bank (2019). World Development Indicators. Per Capita CO2 Emissions in Central Asia. Retrieved

from

https://databank.worldbank.org/data/reports.aspx?source=2\&series=NY.GDP.PCAP.CD\&cou ntry=\#.

World Bank (2019). World Development Indicators. Per Capita Energy Consumption in Central Asia. Retrieved from https://databank.worldbank.org/data/reports.aspx?source=2\&series=NY.GDP.PCAP.CD\&country=\#. World Bank (2019). World Development Indicators. Per Capita GDP in Central Asia. Retrieved from https://databank.worldbank.org/data/reports.aspx?source=2\&series=NY.GDP.PCAP.CD\&country=\#.

Zhang, X. P., \& Cheng, X. M. (2009). Energy Consumption, Carbon Emissions, and Economic Growth in China. Ecological Economics, 68, 2706-2712. https://doi.org/10.1016/j.ecolecon.2009.05.011 
Anh Tru Nguyen

\section{Appendix}

\section{Table A1. Estimation of the VAR Model}

\begin{tabular}{|c|c|c|c|c|c|}
\hline \multicolumn{2}{|l|}{ Variables } & Coefficient & Std. Error & $\mathbf{Z}$ & P-value \\
\hline \multicolumn{6}{|l|}{ LnPer capita GDP } \\
\hline \multirow[t]{4}{*}{ LnPer capita GDP } & L1 & $0.802 * * *$ & 0.08 & 9.07 & 0.000 \\
\hline & $\mathrm{L} 2$ & 0.022 & 0.09 & 0.24 & 0.808 \\
\hline & L3 & $0.338 * * *$ & 0.09 & 3.60 & 0.000 \\
\hline & L4 & $-0.287 * * *$ & 0.08 & -3.58 & 0.000 \\
\hline \multirow{4}{*}{$\begin{array}{l}\text { LnPer capita energy } \\
\text { consumption }\end{array}$} & L1 & 0.019 & 0.02 & 0.99 & 0.321 \\
\hline & L2 & 0.006 & 0.02 & 0.27 & 0.786 \\
\hline & L3 & $0.121 * * *$ & 0.02 & 4.87 & 0.000 \\
\hline & L4 & -0.047 & 0.03 & -1.55 & 0.120 \\
\hline \multirow{4}{*}{$\begin{array}{l}\text { LnPer capita } \mathrm{CO}_{2} \\
\text { emissions }\end{array}$} & L1 & 0.060 & 0.07 & 0.82 & 0.411 \\
\hline & $\mathrm{L} 2$ & -0.139 & 0.09 & -1.44 & 0.151 \\
\hline & L3 & $0.407^{* * *}$ & 0.09 & 4.08 & 0.000 \\
\hline & L4 & $-0.336 * * *$ & 0.08 & -4.00 & 0.000 \\
\hline Constant & & 0.273 & 0.33 & 0.81 & 0.421 \\
\hline \multicolumn{6}{|c|}{ LnPer capita energy consumption } \\
\hline \multirow[t]{4}{*}{ LnPer capita GDP } & L1 & 0.671 & 0.60 & 1.11 & 0.267 \\
\hline & $\mathrm{L} 2$ & -0.454 & 0.64 & -0.71 & 0.478 \\
\hline & L3 & $-1.376 * *$ & 0.64 & -2.14 & 0.032 \\
\hline & L4 & 0.529 & 0.54 & 0.96 & 0.336 \\
\hline \multirow{4}{*}{$\begin{array}{l}\text { LnPer capita energy } \\
\text { consumption }\end{array}$} & L1 & $0.791 * * *$ & 0.13 & 5.80 & 0.000 \\
\hline & $\mathrm{L} 2$ & -0.112 & 0.16 & -0.67 & 0.500 \\
\hline & L3 & $-0.496 * * *$ & 0.17 & -2.91 & 0.004 \\
\hline & L4 & 0.140 & 0.21 & 0.67 & 0.504 \\
\hline \multirow{4}{*}{$\begin{array}{l}\text { LnPer capita } \mathrm{CO}_{2} \\
\text { emissions }\end{array}$} & L1 & 0.051 & 0.50 & 0.10 & 0.918 \\
\hline & $\mathrm{L} 2$ & 0.507 & 0.66 & 0.76 & 0.445 \\
\hline & L3 & -0.547 & 0.68 & -0.80 & 0.422 \\
\hline & L4 & 0.819 & 0.57 & 1.43 & 0.154 \\
\hline Constant & & $7.799 * * *$ & 2.31 & 3.37 & 0.001 \\
\hline \multicolumn{6}{|c|}{ LnPer capita $\mathrm{CO}_{2}$ emissions } \\
\hline \multirow[t]{4}{*}{ LnPer capita GDP } & L1 & 0.162 & 0.16 & 0.99 & 0.320 \\
\hline & $\mathrm{L} 2$ & -0.134 & 0.17 & -0.78 & 0.436 \\
\hline & L3 & -0.154 & 0.17 & -0.89 & 0.374 \\
\hline & L4 & 0.044 & 0.14 & 0.30 & 0.766 \\
\hline \multirow{4}{*}{$\begin{array}{l}\text { LnPer capita energy } \\
\text { consumption }\end{array}$} & L1 & 0.021 & 0.03 & 0.59 & 0.558 \\
\hline & L2 & -0.048 & 0.04 & -1.08 & 0.281 \\
\hline & L3 & -0.066 & 0.04 & -1.44 & 0.151 \\
\hline & L4 & 0.032 & 0.05 & 0.57 & 0.568 \\
\hline \multirow{4}{*}{$\begin{array}{l}\text { LnPer capita } \mathrm{CO}_{2} \\
\text { emissions }\end{array}$} & L1 & $0.889 * * *$ & 0.13 & 6.57 & 0.000 \\
\hline & L2 & 0.112 & 0.17 & 0.63 & 0.529 \\
\hline & L3 & 0.042 & 0.18 & 0.23 & 0.816 \\
\hline & L4 & -0.024 & 0.15 & -0.16 & 0.877 \\
\hline Constant & & 0.921 & 0.62 & 1.47 & 0.140 \\
\hline
\end{tabular}

Source: Author's calculation, 2019, Notes: L1, L2, L3, and L4 mean lag 1, lag 2, lag 3, and lag 4, respectively; $* * *$ and $* *$ denote statistical significance at $1 \%$ and $5 \%$, respectively. 